\title{
Somogy megye katonalegyek katalógusa (Diptera: Stratiomyidae)
}

\author{
MAJER JÓZSEF
}

\begin{abstract}
MAJER J.: Checklist of soldierfly of Somogy county (Diptera: Stratiomyidae)
Abstract: The author summarised faunistical investigations carried out in Somogy county concerning the soldierfly family. About 50 startiomyid species are known in Hungary, 42 species were collected in the region. The fauna of soldier fly best surveyed in this county in Hungary. 4-5 more species are expected. These mostly colourful flies were found in resting position with closed wings on the vegetation; males sometimes dance in the air. Larvae sometimes live among leaf litter or else in water, some of them, for example, the carnivorous Stratiomys feed on debris and other small insects.
\end{abstract}

\section{Bevezetés}

Hazánkban a családot 50-nél több faj képviseli. Somogy megyéből 41 fajt sikerült megtalálni, jelentős részüket Tóth Sándor gyújtötte. A fajlisták kisebbik fele korábban már megjelent (MAJER, 1977, 1985). Rendszeres kutatással a fajok száma még 4-5-el emelkedhet. A család az elmúlt 50 év alatt felosztását tekintve szinte folyamatos átalakuláson ment át. Mivel lárváik zömmel nedves talajban és korhadó avarban, vagy vízben fejlődnek, ilyenekben a megye bövelkedik, ezért a régió e család fajaiban gazdag. Lényeges változásokat találunk az alcsaládok elrendezésében. ROZKOŠNÝ (1982-1983) munkája ezeket részben már tartalmazza. NAGATOMI \& IWATA (1981), ROZKOŠNÝ és NARTSUK (1988), NAGATOMI (1991, 1992) további vizsgálatai nyomán a csoportot 13 alcsaládra osztották fel (nem egy közülük a továbbiakban önálló családdá léphet elö). Ebból 9 alcsalád 400 fajjal a Palaearktikumban is megtalálható. A korábbi Xylomyinae alcsalád végleg önálló család lett, bár korábban a csoport már szerepelt Solvidae néven is (NAGATOMI 1992). A katonalegyekhez igen változatos formájú és életmódú legyek tartoznak. Néhány gyakoribb faj elốkerült a Balaton déli partjáról, amelyek a Természettudományi Múzeum gyújteményében találhatók (MAJER 1977). Somogyból eddig mindössze 7 faj került publikálásra (MAJER 1988), a Barcsi Borókásból. A listán ismertetett fajok többségét Somogyból eddig még nem publikálták. Tóth Sándor 1974-1996 között 31 fajt talált a megyében végzett igen szisztematikus gyưjtései során. Bár az adatok nyomtatásban még nem jelentek meg, a kolléga volt szíves az adatokat rendelkezésünkre bocsátani. Önzetlen segítségének köszönhető a lista ilyen mértékú teljessége. Az eddig ismert hazai katonalégy fajok $80 \%$-a elókerült a megyéból. Ennek ellenére e változatos élôhelyekkel rendelkező vidékról további, még hazai faunára is új fajok várhatók. 


\section{Somogy megyéból ismert fajok}

\section{Beridinae}

Allognosta vagans (Loew, 1843) - Tóth S. Actina chalybea Meigen, $1804^{\circ}$ - Majer J.

Tóth S.

Beris chalybata (Forster, 1771) - Tóth S.

Beris clavipes (Linnaeus, 1767) - Majer J.,

Tóth S.

Beris fuscipes Meigen, 1820 - Majer J., Tóth S.

Beris morrisii Dale, 1841 - Majer J., Tóth S.

Beris vallata (Forster, 1771 ) - Tóth S.

Chorisops tibialis (Meigen, 1820) - Majer J.,

Tóth S.

\section{Sarginae}

Chloromyia formosa (Scopoli, 1763) - Majer J., Tóth S.

Chloromyia speciosa (Macquart, 1834) -

Majer J., Tóth S,

Microchrysa flavicornis (Meigen, 1822) -

Tóth S.

Microchrysa polita (Linnaeus, 1758) - Majer J.,

Tóth S.

Sargus bipunctatus (Scopoli, 1763) - Majer J.,

Tóth S.

Sargus cuprarius (Linnaeus, 1758) - Majer J., Tóth S.

Sargus flavipes Meigen, 1822 - Tóth S. Tóth S.

Sargus iridatus (Scopoli, 1763) - Majer J.,

\section{Stratiomyinae}

Odontomyia angulata (Panzer, 1798) - Majer, J.

Odontomyia argentata (Fabricius, 1794) Tóth S.

Odontomyia hydroleon (Linnaeus, 1758). Majer I.

Odontomyia ornata (Linnaeus, 1758) - Tóth S.

Odontomyia tigrina (Fabricius, 1775) - Tóth S.
Oplodontha viridula (Fabricius, 1775) - Tóth S.

Stratiomys cenisia Meigen, 1822 - Majer J., Tóth S.

Stratiomys chamaeleon (Linnaeus, 1758) -

Majer J., Tóth S.

Stratiomys longicornis (Scopoli, 1763) -

Majer J., Tóth S.

Stratiomys potamida Meigen, 1822 - Tóth S.

Stratiomys singularior (Harris, 1776) - Tóth S.

\section{Clitellariinae}

Clitellaria ephippium (Fabricius, I775) -

Majer J., Tóth S.

Lasiopa calva (Meigen, 1822) - Majer J.

Lasiopa villosa (Fabricius, 1794) - Majer J., Tóth S.

Nemotelus nigrinus Fallén, 1817 - Majer J.

Nemotelus pantherinus (Linnaeus, 1758) -

Majer J., Tóth S.

Nemotelus uliginosus (Linnaeus, 1767) -

Majer J.Tóth S.

Oxycera leonina (Panzer, 1798) - Majer J.,

Tóth S.

Oxycera morrisii Curtis, 1830 - Majer J.

Oxycera nigricomis Olivier, 1812 - Tóth S.

Oxycera pygmaea (Fallén, 1817) - Tóth S.

Oxycera trilineata (Linnaeus, 767) - Majer J., Tóth S.

\section{Pachygasterinae}

Eupachygaster tarsalis (Zetterstedt, 1842) -

Majer J.

Pachygaster atra (Panzer, 1798) - Majer J., Tóth S.

Pachygaster leachii (Curtis, 1824) - Tóth S.

Zabrachia minutissima (Zetterstedt, 1838) -

Tóth S.

\section{1. táblázat: Somogyból ismert fajok száma}

\begin{tabular}{|l|c|}
\hline Rend, Család & Fajszám \\
\hline Diptera & \\
\hline Stratiomyidae & 42 \\
\hline
\end{tabular}




\title{
Irodalom
}

MAJER, J., 1985: Adatok a Barcsi Borókás katonalégy (Stratiomyidae), kószalégy (Rhagionidae) és rablólégy (Asilidae) faunájához (Diptera). - Dunántúli Dogozatok Természettudományi sorozat, 5: 139-144

NaGatomi, A. 1991: History of some families of Diptera, chiefly those of the Lower Brachycera (Insecta: Diptera). Bull. Biogeogr. Soc. Japan 46: 21-37.

NAGATOMi, A. 1992: Notes on the phylogeny of various taxa of the orthorrhaphous Brachycera (Insecta: Diptera). Zool. Sci. 9: 843-857.

NAGATOMI, A. \& IWATA K. 1981: Female terminalia and systematic position of some Stratiomyidae (Diptera). Kontyu 49: 563- 576.

RoZKoŠNÝ, R . 1982-1983: A biosystematic study of the European Stratiomyidae (Diptera). Vol. $\mathrm{l}$ and 2. W. Junk, The Hague, Boston, London, pp. $401+431$

Rozkošný, R. \& NARTsuk, E. P. 1988: Family Stratiomyidae. In Soós Á. \& Papp, L., Catalogue of Palaearctic Diptera. Vol. 5. Akadémiai Kiadó, Budapest, pp. 42-96.

\section{Checklist of soldierfly of Somogy county (Diptera: Stratiomyidae)}

\author{
JÓZSEF MAJER
}

In the soldierfly (Stratiomyidae) family 42 species were registered in Somogy county. About 50 Startiomyid species are known in Hungary, $80 \%$ of them were collected in the region. 4-5 more species are expected.

\author{
Author's address: \\ Dr. József MAJer \\ Department of General and Applied Ecology \\ University of Pécs \\ 7601 Pécs \\ Ifjúság útja 6 . \\ HUNGARY
}

